Dorota Dakowska, «Higher Education in Poland: Budgetary Constraints and International Aspirations ", in: Jon Nixon (ED.), Higher Education in Austerity Europe, Bloomsbury, 2017, p. 79-91.

\title{
Higher Education in Poland: Budgetary Constraints and International Aspirations
}

\author{
Dorota Dakowska
}

In October 2015, the Crisis Committee of Polish Humanities organized a happening in front of the Academy of Science building in Warsaw. In a symbolic gesture, a few young researchers-activists burned their scientific output to the sound of a funeral march while some colleagues and trade unionists distributed an open letter and information material. This was a reaction to official communiqués published by the Ministry of Education and Science (Ministry), which claimed that conditions of research were improving thanks to competitionoriented, market-friendly policies. The protesters countered that higher education (HE) in Poland was undergoing a deep crisis due to insufficient funding and low wages. A few weeks later, the electoral victory of the national-conservative Law and Justice party triggered mass demonstrations throughout the country following the new government's attempts to weaken the Constitutional Court and limit media freedom. As the neo-liberal policy discourse that had until then prevailed, appeared to vanish, public discontent grew, and the very foundations of democratic institutions were called into question.

The case of Central and Eastern European Countries (CEEC) invites us to reconsider the temporal and political aspects of the reconfiguration of $\mathrm{HE}$ with regard to austerity measures. The new European Union (EU) member states have not been hit by the post-2008 financial and economic crisis in the same way as some of their Western counterparts. While Central and Eastern European universities have been affected by cuts in public expenditure and privatization of $\mathrm{HE}$, it is worth recalling three facts. First, these countries were neither directly nor equally impacted by the crisis (some of them were already Eurozone members, others were not). Secondly, the major disruption of their HE system occurred in the beginning of the 1990s after the communist regimes collapsed (Sigman, 2014; Cîrstocea, Dakowska Sigman, 2014). Thirdly, the changes that affected the status and conditions of academic work resulted mainly from voluntary measures undertaken by governments in the region in the name of 'excellence', 'quality' and international 'competitiveness' of HE and research institutions. Thus the political materiality of austerity policies must be analyzed case by case. 
This contribution will focus on the Polish case, which has been characterized, since 1989, by a neo-liberal policy orientation. ${ }^{1}$ Notwithstanding the small state ideology promoted by most governments, HE policies were marked by ambiguity. On the one hand, the decision to give back autonomy to universities was intended to limit state control of academic governance. On the other hand, the state kept intervening in curricula, public financing and public steering of teaching and research (Dobbins 2011, 2015). The Polish case, which will be discussed here, is not an isolated example. It may be considered as a regional illustration of the Central and Eastern European countries as 'laboratories of reform' characterized by a strong openness to external reform recommendations, budgetary pressure and a policy preference for the competitive orientation of grants (Dakowska, Harmsen, 2015).

Following the general framework of this book, the Polish case exemplifies the way austerity has been applied to academia in the form of cuts in public expenditure, competitive financing and far-reaching privatization. The contribution focuses on different stages that led to the increasingly competitive orientation of $\mathrm{HE}$ and research. Beyond policy conception and implementation, I consider how these competitive mechanisms of grant distribution are perceived by academics but also by the policy entrepreneurs who promote them. Following an interpretative policy inquiry, the contribution 'attempts to "understand" or "make sense of" social phenomena in terms of social actors' own motives, goals and explanations' (Fischer, 1995, p. 242).

The chapter is structured as follows. The first part examines the international dimension of Polish HE redesign and documents the increasingly competitive orientation of the Polish academic sector. The second part looks into how budgetary constraints and the competitive orientation of teaching and research influence academic life. I ask how these new norms are perceived and interpreted both by users and those who are supposed to explain and enforce them. I conclude that the dividing line between the norm enforcers and users is not as clearcut as could be expected. This leads me to reconsider the commonly admitted distinction between the winners and losers of austerity reforms.

\section{In the name of excellence. The competitive orientation of Polish Higher Education}

In Poland, the Eurozone crisis cannot be viewed as the main trigger of the HE system's redesign, for two main reasons. First, the Polish economy has not been hit by economic turmoil to the same extent as some West European countries. Secondly, the main austerity measures affected the country's public sector following the fall of the Communist regime in 1989 and were due to the neo-liberal 'shock therapy' implemented by the first democratic governments. Like other countries of the region, Polish academia has experienced similar pressures to massify and privatize higher education (Slantcheva, Levy, 2007; Levy, 2012). However, these policy trends are connected to domestic political configurations. A study conducted by the Polish Rectors' Conference showed that while the HE reforms of 1990,

\footnotetext{
${ }^{1}$ This analysis is based on different types of documents related to the reforms (legal acts, published and unpublished reports, communiqués, as well as press articles) and on over 80 semi-structured interviews conducted between 2010 and 2016, mainly in Poland but also in France, Germany, Brussels and Ukraine with HE experts, national and international civil servants, and representatives of the academic community.
} 
2005 and 2011 were meant to strengthen the universities' autonomy, they also led to a degree of overregulation (Woznicki, 2013). Thus, the Rectors have asked for a deregulation of HE, especially as far as HE organisation, internal fund distribution, research but also staff policy are concerned.

While the number of competitive grants has steadily grown since 2010, this is largely due to the measures undertaken by the liberal governments in power from 2007 to 2015, which launched several major reforms of the academic sector. This part will show that the Polish HE system has been permeable to a reformist discourse based on neo-liberal ideas (which value the notions of competition and market-orientation) and has sought international and European legitimation of the reform frameworks. Although this chapter focuses on HE, I take into account policy instruments designed for the governance of the research sector, as they have affected the everyday life of academics and were designed by the same Ministry. ${ }^{2}$

\section{External inspirations in competitive policy measures}

At the beginning of the 1990s, Central European HE systems were recipients of the assistance programmes of institutions active in the field of education such as the OECD, UNESCO and the Council of Europe but also the World Bank and several private organisations. The first post-1989 Polish democratic governments adopted HE and Research reforms, whose international inspirations did not necessarily stem from Europe. For instance, the State Committee for Scientific Research (KBN), created in 1991, which institutionalised the principle of competition between researchers applying for grants, was inspired by the US National Science Foundation (NSF) (Jabłecka, 2009). ${ }^{3}$ The main initiator of the KBN project was Stefan Amsterdamski (1929-2005), a professor of philosophy who has accumulated outstanding academic, international and political resources. ${ }^{4}$

The creation of the Committee for Scientific Research reflects the converging views shared both by opposition experts and representatives of the new democratic government. It aimed at creating a self-governing body made up of elected research community representatives and at setting up conditions for the allocation of public grants based on peer reviewing. Several features of the system (peer review, goal-oriented projects) were inspired by external models of research funding and organization (mainly from US agencies, but also Canadian, British, Dutch and German research councils) (Jabłecka, 2009).

The financing of HE and Research has been among the main interests of international organizations. In the first half of the 1990s, the advisors sent by the Council of Europe to CEEC had noted that the higher education sector was underfinanced. They recalled that student fees and resources coming from the private sector had a limited contribution to the

\footnotetext{
${ }^{2}$ The Polish academic system is characterised by a distinction between the universities and other higher education institutions on the one hand and the institutes of the Academy of Science on the other hand. The latter are more exclusively focused on research.

${ }^{3}$ Before the creation of the KBN, the principle of competition for grants had been established, also based on the US example. The American Embassy financed several study trips of Polish researchers and governmental advisors. These exchanges have inspired, among others, the creation of accreditation bodies.

${ }^{4}$ Amsterdamski had been both an intellectual public figure and a politically engaged member of the democratic opposition movement. He was a visiting fellow in many prestigious international academic centres. After his involvement in the so-called Round Table negotiations between the opposition and the Communist government (January-April 1989), he entered the first democratic government as secretary of state, and he was entrusted with the mission to create the KBN. http://www.css.edu.pl/sns/amsterdamski_en.php
} 
institutional budgets. The CoE delegates called to increase the percentage of state budget allocated to higher education. This demand was based on the claim that HE institutions were leading driving forces of economic development. In comparison with the Council of Europe, the World Bank promoted a more economically liberal vision of HE. In a report on Polish tertiary education it called for the diversification of HE revenues and the generalisation of fees (World Bank, 2004). Although fee-paying courses mushroomed throughout the country in the 1990s, the recommendation concerning the generalisation of fees has not seen any official policy translation so far, as higher education has remained constitutionally free of charge (even if in effect a high percentage of students do pay fees). This shows that the recommendations of international organisations may diverge.

In the beginning of the 1990s, European Union programmes contributed to opening up Polish universities and researchers to international exchanges and organisational standards. The European Commission's Tempus programme allowed university teachers and managers to become familiar with Western European university systems during exchanges and site visits. Some of the participants in the Tempus mobility scheme were able to reinvest the knowledge of foreign HE systems they had accumulated during the exchange programmes and become HE experts. The launching of the EU accession process increased the receptiveness of political and academic elites to external incentives. After the accession, the EU funds contributed to the restructuring of the HE sector. In the HE modernisation strategy published in 2011 the European Commission identified the necessity 'to increase investment in higher education and to diversify funding sources, drawing to a larger extent on private funding' and called for more flexible, results-based funding systems based on 'an element of competition' (European Commission, 2011). EU funds have not only facilitated the internationalisation and reform of Polish HE. They contribute to a considerable part of the HE and research budget. ${ }^{5}$ This has raised some concern as to the post-2020 budgetary perspective, when the amount of structural funds allocated to Poland might decrease.

\section{The Polish treatment of austerity in higher education}

Due to the dramatic increase in student enrolment in the early 1990s, HE institutions faced major funding problems. As high level representatives of the Ministry of National Education explained during an advisory mission of the CoE in Warsaw, the increase in the number of students (by 70\% between 1989 and 1993) caused the annual budget per student to drop from $1630 \$$ in 1989 to $1100 \$$ in 1993 and under $900 \$$ in $1994^{6}$. The first major HE Act, adopted in September 1990, included flexible regulations that ensured autonomy and collegiality for universities. One of the side effects of that law was a far-reaching privatisation of HE, due to the provisions on fee-charging courses, which introduced the distinction between full-time day studies, evening studies and extramural studies (Jabłecka, 2007). As the 1990 HE Act

\footnotetext{
${ }^{5}$ In $2013,26.6 \%$ of the overall budget for science came from EU funds. In 2014, the proportion reached $29 \%$. Author's calculations based on data from the 2014 budget report of the Ministry of Science, part 28, Science. Warsaw, May 2015, p. 10.

${ }^{6}$ Council of Europe, DECS LRP 95/19, Higher Education and Research Committee, Legislative Reform Programme for Higher Education. Poland, Report of the Advisory Mission on Quality Assessment and Accreditation, Warsaw, 26-29 September 1994, p. 4.
} 
limited the Ministry's formal control, the development of an accreditation and quality evaluation system became a priority.

A key point to understand the perception of austerity measures by the academic community is the fact that HE policy was not so much based on radical budget cuts as on a new system for allocating funds. Compared to other European countries, the evolution of global expenditure on tertiary education in Poland falls in the average category. As far as the evolution of the share of public expenditure allocated to tertiary education between 2005, 2008 and 2011 is concerned, Poland belongs to the third group of countries where 'public expenditure on tertiary education increased at a slower pace than public expenditure (or decreased more rapidly than public expenditure)' (European Commission, 2015, p. 40). In these countries, the percentage of total public expenditure devoted to tertiary education was lower in 2011 than in 2005. Other members of this group are Norway, Iceland, Ireland and the United Kingdom. While between 2005 and 2011 the Polish per capita expenditure for tertiary students accounted for a decreasing share of the GDP, this is mainly due to the fact that public expenditure increased at a slower pace than the GDP per capita. Regarding that indicator Poland was part of a group of countries that included Bulgaria, the Netherlands, Romania, Slovakia and Norway (European Commission, 2015). This situation caused alarm among representatives of the Polish academic community. In June 2015 its leaders sent an open letter to the Prime Minister, in which they regretted the continuing decrease of funds for HE and research since 2010 . The state of affairs that they were denouncing obviously related to the increasingly competitive research funding system.

Although the principle of competitive grant allocation was endorsed throughout the $1990 \mathrm{~s}$, the share of the budget distributed in such a form initially remained limited. The situation changed after 2007, especially with the 2010 law on Research and 2011 law on Higher Education (Dakowska, 2013). ${ }^{7}$ These legal acts established new grant distributing agencies: the National Research Centre (NCN) for fundamental research and the National Centre for Research and Development, (NCBiR), which supports applied research projects and cooperation with industry. Commenting these legal acts, the HE Minister Barbara Kudrycka stated that she wanted to 'introduce a maximum of open competition mechanisms, also as far as fundraising is concerned' (Kudrycka, 2010, p. 6). In 2012, extra funds were earmarked for the so-called Leading National Research Centres (KNOW) selected upon parametric evaluation and quantitative indicators of 'scientific efficiency'. Prizes and scholarships were created to distinguish the best (especially young) scholars ('Diamond grant', 'The best of the best' etc.). As a result of these policy measures, the research budget, which, until 2010, was almost entirely distributed by the Ministry, underwent a radical transformation. The share of this budget allocated to competitive grants has steadily grown in the past years, and now exceeds $50 \%$.

In order to differentiate the country's research units, these legal acts introduced a system of parametric evaluation, which pushes them to increase their publications in English-language, peer-reviewed journals. This measure of their scientific output introduced new hierarchies between and within research units. This evaluation draws heavily on international journal databases and citations as the Ministry has established three lists of journal titles. The first

\footnotetext{
${ }^{7}$ Both Acts have been amended several times since then.
} 
and most rewarding includes journals with an impact factor from the Journal Citation Reports database (awarding up to 50 points per article published). The second contains mainly Polish journals (awarding up to ten points and, more recently, up to 15 points per publication). The third one is the much-debated European Reference Index for the Humanities (ERIH). ${ }^{8}$

The heated debates on the low number of points attributed to Polish-language publications and the damage it could cause to the humanities led to the adoption of specific criteria to take into account the specificities of these disciplines. Yet, the distribution of public funds to research units has since been further regulated. According to the new algorithm, the basis allocation for a category $\mathrm{A}+$ research units must be multiplied by 1.5 ; category $\mathrm{A}$ units by is 1.0 ; category $\mathrm{B}$ units by 0.7 ; and category $\mathrm{C}$ units by 0.4 , which may force them to close (Ministry, 2015, p. 9). This policy has caused significant gaps to develop between HE institutions, research centres and last but not least, individual academics themselves. The next section examines how these measures were perceived by the academic community.

\section{Coproducing and enduring reforms. The Polish case}

There have been increasing numbers of comparative studies of the academic profession since the 1970s (Altbach, 1977; Clark, 1987). They were a major focus of higher education studies in the 1990s (Boyer \& al., 1994; Altbach, 1996). Already at the time the idea of a perceived 'crisis' of the profession was advanced in the context of the massification of higher education, its loss of monopoly on knowledge production, the diversification of academic work and the contradictory pressures that affected it (Enders, 1999). In the following part I will examine how domestic reinterpretations of international recommendations combined with austerity measures reflecting a neoliberal conception of the managerial state affect academic work.

\section{Focusing on internationalized academic entrepreneurs}

Following a sociological-constructivist approach I take into account the 'meso' and even the 'micro' level, i.e. the organised interest groups and academic experts involved in public policy debates and reform design. The agency of HE reform remains an under-investigated research field. Usually the European Commission or international organisations as a whole are presented as actors. Sociological policy analysis calls for investigating either contextual issues (the policy origin and main players), textual issues (who has advocated and promoted the policy and why? where are these advocates located?); policy structuring (focused on policy communities, the role of international agencies and policy borrowing) or policy implementation (Rizvi, Lingard, 2009: 54-55). Therefore I consider the transformations of the Polish HE system by focusing on the individuals and groups involved in promoting external models of HE management, engaging in international cooperation or explaining European policy frameworks to the academic community.

For the purposes of this paper I focus on the individuals who have been involved in the internationalisation strategies through their own practice at the HEI level and are familiar with

\footnotetext{
${ }^{8}$ Launched by the European Science Foundation (ESF), ERIH stagnated during the decline of the ESF. In 2014 it was overtaken by the Norwegian Social Science Data Services (NSD) and is now available as ERIH plus.
} 
the national and international policy levels. This population includes both academics involved in expert groups linked with the European Higher Education Area (EHEA) and those who have experienced the reforms through their everyday practice of academic international cooperation. While the former contribute to translating the frames and narratives developed abroad into domestic spaces, the latter struggle to apply them.

Although a majority of these individuals have accumulated international experience, before 1989 or in its aftermath, their positions in the academic space vary. Some experts combine a traditional academic career with their expert activities. Others may hold an official position at the university but have invested more in their expert activities. Although the academic experts may have a more positive perception of international recommendations than the lecturers, both groups are aware of the side effects linked to their implementation.

\section{The new academic life under the constraints of evaluation}

While HE reforms in Poland have been dominated by a neo-liberal approach, they initially affected mainly teaching with the expansion of fee-paying courses. The 2010-2011 reforms showcased a managerial approach to $\mathrm{HE}$ and research policy. As the share of grants earmarked for competitive funding has steadily grown, getting a grant has become a condition sine qua non to carry on with academic activities such as participating in conferences or doing field research. At the same time, the competitive orientation of the grant-giving institutions has made access to them more and more difficult (the success rate of grant applications submitted to the NCN is currently about $15 \%$ ).

Since 2010 the evaluation of research has become a major component of academic life in Poland. While individual researchers are supposed to be evaluated every two years, their research institutes have to publish regular reports on their scientific productivity. The bibliometric measurement of published articles has become the basis for the allocation of grants. Thus, in the past few years, it has become clear to academics that their scientific output is directly correlated with the financing they are able to secure either individually or through their institute. This puts huge pressure on the academics themselves, on their relationships with their peers and on the organization of academic work. As they are drowning in paperwork and overloaded with teaching, university lecturers find it increasingly difficult to fulfil their traditional missions.

'We have to do with a real product whose position is measurable with a $C V$. I am the product. I have the impression that following this whole transformation I have become a product. I have some writing skills, some linguistic knowledge, which make me a decent quality product to sell on the international scientific market. Which means that I feel I am not doing science any more. There is frustration in me. If I had known I would live that way, that science would become an alibi...'.

(Senior lecturer, M, Social science, University of South, 2014)

Facing the international academic competition has become a mantra for pro-reformist experts. This ubiquitous discourse has few open adversaries. But even scholars who do not oppose it openly and are used to publishing in English may express negative views. 
'These points are so pervasive; even in the evaluation of employees everything is classified according to these points. How many reviews do I have from the ERIH list, how many from another list... Sometimes I don't even know, I have to look, because it changes from year to year. So this leads to specific choices and consequences. (...) There is a feeling of injustice. And we waste a lot of time on checking points, calculating, searching for data, filling forms. Now we have a new system where we have to put all our publications - how many points a given publication has and I think we have to attach the pdf. So this bureaucracy is thriving and I have to take care of it instead of writing, preparing courses, doing research - it's a kind of sick thinking'.

(Associate professor, F, Social science, University of West, 2015).

The feeling of competition between colleagues from the same unit - which grows as regular funding is shrinking - has become a major element of everyday academic life.

'In my view it is a worrying question because in the department where I am employed, also due to the great passivity of a large part of the academic staff, a considerable part of the points are produced by the doctoral candidates who are groomed to compete with each other while their publications are counted among the publications of the unit. This reflects a kind of paradox. The PhD candidates are not employees and the framework of points, which was initially not meant to evaluate employees, is used to quantify and to establish hierarchies in the doctoral population in the struggle for a very scarce amount of scholarships'.

(Junior researcher, M, Humanities, University of West, 2015)

Even among the younger generation of academics, who have been acquainted with foreign university systems and are supposed more open to change (Kwiek, 2015), this situation may lead to frustration, a feeling of alienation or difficulties to cope with these new working conditions.

'I feel as if I have been hired under completely different conditions. Not for this kind of race, (...) for always being compared (...) All this is sick and ridiculous, right? But this system forces this kind of pushing and shoving... I mean some people do it, some don't. But we do not cooperate; it seems to me that people are increasingly rivals'.

(Associate professor, F, Social science, University of West, 2015).

Even if they care about their profession and consider their job as a vocation, the neomanagerial functioning of $\mathrm{HE}$ institutions forces them to rethink their entire conception of academic work.

'If we provoke a situation, in which the university, academia has become a corporation like any other in the sense that we have a client, we have a product, we have to fight for our international position, then I have to wonder whether this way of making money suits me'.

(Senior lecturer, Social science, University of South, 2014)

While academic teachers try to accommodate these new rules academic experts are unequally convinced of their fairness. 


\section{The higher education reformers under pressure}

The competitive orientation of HE reforms has been promoted by academic reformers who may be compared to Howard Becker's (1963) 'moral entrepreneurs'. On the one hand the 'rule creators', and especially 'crusading reformers' want to change the existing rules in which they see some evil. In the Polish case, this category may be applied to experts involved in the reform design, either by sketching the reform projects or by making public statements on the desired reform shape.

'In order to create high quality HEIs, we need differentiation and competition. The main disease of public higher education is lack of competition. Only competition is able to boost initiative, to develop heterogeneity and to create conditions allowing the best to reach excellence. There is no better mechanism to eliminate faculties and professors who teach poorly'

(Thieme, 2009, p. 10-11)

On the other hand, the 'rule enforcers' work in organisations that have been specifically set up to enforce the rule. They have 'no stake in the content of particular rules themselves' and may 'develop their own private evaluation of the importance of various kinds of rules and infractions on them' (Becker, 1963, p. 161). Experts who have been nominated to represent their disciplines in various evaluation bodies may be included in this category. However, unlike Becker's moral entrepreneurs, these experts who seek to enforce the new evaluation procedures are themselves bound by them, as they remain members of academic research units.

In order to better seize the tensions inherent in the implementation of new rules I have asked the rule enforcers themselves how they define, refine and deal with these rules. These experts act as brokers between the academic community and the Ministry. They have been chosen for their technical knowledge in bibliometrics but also for their experience of representative functions in international academic bodies and European expert groups. Like Howard Becker's crusaders they believe in the necessity to hierarchize the academic profession and to create mechanisms which trigger 'excellence'. At the same time, due to their position of users, i.e. of academics, whose research centres are being evaluated under the new rules, they may assume a critical distance from the rules they have themselves contributed to elaborate. As they receive numerous complaints through their networks, they tend to consider parametric evaluation not as a panacea but as a lesser evil.

One way of expressing a critical distance from the new rules is to admit the side effects they may produce. The fact that the new evaluation rules largely privileges English-language journals and large publishing houses may cause some disillusion. A member of an expert group might get emotional talking about their own research field and the growing dominance of the Scopus database in the evaluation of research. The awareness of the predominant market mechanisms and editorial strategies of market leaders are another source of concern.

"I remember how shocked I was when I learned that the corporation Elsevier has a policy - as it picks up the journals which will integrate the Scopus list-a policy linked with its own distribution and sales market (....). I looked at the humanities as a whole 
and then I looked at specific disciplines. And it was all the same: United States, Great Britain and in third place, the Netherlands. The Netherlands as an editorial power. So this means they are promoting their own pool of journals, their own! Ukraine: Zero! Lithuania: Zero! Scandinavia: Zero. (...) So how can I consider such a list seriously? Why should a list shaped by a firm according to some market principles guide my scientific activities??"

(Professor, F, Humanities, Academy of Science, 2015)

The experts who shape the bibliometric evaluation of research do not all share the same views. The hesitations expressed by some of them shed light on the tensions that may emerge between different disciplines or between the bibliometric hardliners and those who defend a softer approach. Beyond diverging views on the relative weight of different criteria, the material impact of evaluation on the research institutes has been debated. Parametric evaluation was intended to reward the most productive research institutions and to sanction the least efficient ones. However, the institutes of the Polish Academy of Science have been particularly hit by these new measures. ${ }^{9}$ Contrary to the university researchers, whose statutory funding relies mainly on teaching missions, the Academy of Science institutes entirely depend on public subsidies for their research activity. The change in the grant distribution method has put some of the institutes in an extremely tense situation.

"The Institute where we stand is in the A category. According to the new algorithm, it got less money than in the previous year. Although as an A unit it shouldn't get less. (...) Some social science and humanities units were, let us say, prejudiced by the new algorithm. In the sense that they got less because of the calculation method. Even in this building, there are institutes who are in the A+ category. And during the first round of funds distribution, [X] the director recalled that they have got $600000 \mathrm{ZL}$ less than in the previous year although they should have been rewarded. Probably this has been corrected but this does not mean... probably he did not get less in the end but did he get more? Rather not. So this distribution system is not perfect yet".

(Professor, M, Social Science, Academy of Science, 2015)

This shows that even the supposed winners of the race for excellence, who have obtained the maximal evaluation grades, do not necessary benefit from the new evaluation rules.

\section{Conclusion}

This contribution illustrates the domestic reinterpretation of external incentives for HE reform in the context of post-communist transformation and EU accession. In Poland, austerity measures concerning HE and research were overshadowed by other policy concerns. The sharp cuts in spending per student were considered, at the political level, as the necessary

\footnotetext{
${ }^{9}$ According to a table forwarded to the author by a leading member of the Academy of Science, out of 14 institutes of the Academy, a vast majority (12) have been ranked A (8) or A+ (4). Still, most of their budget endowments have decreased between 2014 and 2016 and a further decrease due to the new algorithm is expected in 2017 and 2018. The overall budget of these research institutes is thus expected to decrease by $27 \%$ between 2014 and 2018.
} 
outcome of the sharp rise of the students' numbers and of the GDP growth. Furthermore, the narrative on the desired effects of competitive grant distribution has legitimised the cuts that affected research units.

The conditions of academic work are changing rapidly. In Poland, the 2010-2011 legal acts have triggered major changes in how funds are allocated to universities and research units. As a result, universities and faculties have to struggle to secure external grants to survive. Academic writing has become a strategy to raise the number of points necessary to get grants. In this new situation, it is not always easy to distinguish between winners and losers. The academics who endorse the new competition and stratification logic may become grantmaking entrepreneurs. For mid-career academics, following the point-gaining strategy is a way to remain loyal towards their home institutions or towards the professor they depend on. Those who do not have a chance to get a grant because their publications remain too 'local' see their professional perspectives narrowing. In this way winning a grant has become a condition of academic survival. The academic profession in Poland - like in other countries is more and more stratified between those who benefit from the competitive grants and those who do not.

But even the academic entrepreneurs who coproduce the new policy measures end enforce the competitive rules due to their participation in expert groups and evaluation bodies are aware of the side effects of the policy designed to bring about new hierarchies between researchers. In a situation where competitive measures may be a justification for further budgetary cuts, the losers of the reforms can easily be identified, but it is not so clear who is really winning.

\section{References}

Altbach, P. G. (1977), 'Introduction. Notes on the Study of the Academic Profession', Higher Education, 6: 131-4.

Altbach, P. G. (2003), 'Introduction to Higher Education theme issue on the Academic Profession in Central and Eastern Europe', Higher Education, 45(4): 389-89.

Becker, H. (1963), Outsiders. Studies in the sociology of deviance, New York: The Free Press.

Boyer, E. L., P. G. Altbach and M. J. Whitelaw (1994), The Academic Profession: An International Perspective. Princeton, New Jersey: Carnegie Foundation for the Advancement of Teaching.

Clark, B.R., ed (1987), The Academic Profession: National, Disciplinary, and Institutional Settings. Berkeley, California: University of California Press.

Cîrstocea, I., Dorota Dakowska and Carole Sigman (2014) 'Avant-propos', introduction to the special issue "Transformations of Academic Fields in East-Central Europe since 1989." Revue d'études comparatives Est-Ouest 45 (1): 5-19.

Dakowska, D. (2013), 'Polish Higher Education and the Global Academic Competition: University Rankings in the Reform Debates', in: Tero Erkkilä (Ed.), Global University Rankings: Challenges for European Higher Education, Palgrave Macmillan, p. 107-23. 
Dakowska, D. (2015), 'Between Competition Imperative and Europeanisation. The Case of Higher Education Reform in Poland', Higher Education, 69(1): 129-41.

Dobbins, M. (2011), Higher Education Policies in Central and Eastern Europe: Convergence towards a Common Model?, Houndmills, Basingstoke: Palgrave Macmillan.

Dobbins, M. (2015), 'Exploring the governance of Polish public higher education: balancing restored historical legacies with Europeanization and market pressures', European Journal of Higher Education, 5(1): 18-33.

Enders, J. (1999), 'Crisis? What Crisis? The Academic Professions in the "Knowledge» Society', Higher Education, 38(1): 71-81.

European Commission/EACEA/Eurydice (2015), The European Higher Education Area in 2015: Bologna Process Implementation Report. Luxembourg: Publications Office of the European Union.

European Commission, Communication from the Commission to the European Parliament, the Council, the European Economic and Social Committee and the Committee of the Regions of 20 September 2011 - Supporting growth and jobs - an agenda for the modernisation of Europe's higher education systems [COM(2011) 567].

Fischer, F. (1995), Evaluating Public Policy, Chicago, Nelson-Hall Publishers.

Jabłecka, J. (2007), 'Legitimation of Nonpublic Higher Education in Poland', in: Slantcheva, S. \& D. C. Levy, eds., Private Higher Education in Post-Communist Europe. In search of legitimacy. Houndmills: Basingstoke, Palgrave Macmillan.

Jabłecka J. (2009), 'Revolution and evolution in the organization of public research funding in Poland between 1991 and 2007', in J. Jabłecka, Public research funding. Research councils, funding instruments, evolution of the system in Poland, Centre for Science Policy and Higher Education, University of Warsaw.

Kwiek, M. (2015), Academic generations and academic work: Patterns of attitudes, behaviors and research productivity of Polish academics after 1989. Studies in Higher Education, 40(8), 1354-1376.

Kudrycka, B. (2010) 'Uczelnie potrzebują konkurencji' (HEIs Need Competition), interviewed by M. Suchodolska and K. Klinger, Dziennik Gazeta Prawna, 25 May 2010.

Levy, D. C. (2012), 'How Important Is Private Higher Education in Europe? A Regional Analysis in Global Context', European Journal of Education, 47(2): 178-97.

Ministry of Science and Higher Education (2015), 11 September 2015 Regulation on the calculation of funding and regulation of financial means for maintaining scientific potential, scientific research and tasks supporting the development of young researchers and participants in doctoral studies. Polish official journal, $\mathrm{n}^{\circ} 1443$, Warsaw, 22 September 2015.

OECD (2006) OECD Thematic Review of Tertiary Education: Country Background Report for Poland, Warsaw.

Rizvi, F. and B. Lingard (2009), Globalizing education policy, Routledge.

Sigman, C. (2014) 'Les transformations de l'enseignement supérieur en Russie : évolution du secteur public et stratégies d'établissements', Revue d'études comparatives Est-Ouest 45(1): 21-54.

Slantcheva, S. and D. C. Levy, eds. (2007). Private Higher Education in Post-Communist Europe. In search of legitimacy. Houndmills, Basingstoke: Palgrave Macmillan. 
World Bank (2004), Tertiary Education in Poland, Warsaw.

Thieme, J. K. (2009) Szkolnictwo wyższe. Wyzwania XXI wieku. Polska, Europa, USA (Higher Education. Challenges of the 21st Century. Poland, Europe, USA), Warsaw: Engram/Difin.

Woźnicki J. (Ed.) (2013), Financing and Deregulation in Higher Education, Polish Rectors Foundation: Warsaw. 